ROCZNIKI HUMANISTYCZNE

Tom LXIX, zeszyt $12-2021$

DOI: https://doi.org/10.18290/rh216912-10

TOMASZ ROKOSZ

\title{
LIRA KORBOWA - INSTRUMENT ZAPOMNIANY? WSPÓŁCZESNA PRAKTYKA REKONSTRUKCJI I BUDOWANIA INSTRUMENTÓW W PRACOWNI LUTNICZEJ STANISŁAWA NOGAJA
}

Lira korbowa pod wieloma względami wyróżnia się z grupy chordofonów smyczkowych. Możemy tu mówić nawet o swoistej sakralizacji czy wręcz mityzacji instrumentu i praktyk muzycznych z nim związanych. Sytuacja ta jest efektem wysokiego statusu lirnika w społecznościach tradycyjnych XIX i początków XX wieku - jego autorytet poświadczają liczne źródła i opracowania (por. Przerembski, „Z dziejów praktyki lirniczej na ziemiach Rzeczypospolitej”; Kononenko; Michajłowa, Dziad wędrowny jako postać mediacyjna i Dziad wędrowny w kulturze ludowej Stowian; Dahlig; Grochowski). Ten historyczny kontekst w szczególny sposób warunkuje także współczesną recepcję liry korbowej w polskiej kulturze, a zwłaszcza jej wytwarzanie, praktykę wykonawczą i repertuar muzyczny na nią przeznaczony.

W niniejszym artykule poruszona zostanie problematyka współczesnego wytwórstwa omawianego instrumentu. Budowa współczesnych lir niekiedy przyjmuje postać rekonstrukcji określonego, tradycyjnego modelu, częściej jednak wiąże się $\mathrm{z}$ tworzeniem nowych, coraz bardziej udoskonalonych egzemplarzy, odpowiadających współczesnemu zapotrzebowaniu i obowiązującym dziś standardom. Do szczegółowej analizy wybrano problem rekonstrukcji konkretnego muzealnego egzemplarza liry korbowej wykonanego

Dr hab. TOMASz RoKosz - Katolicki Uniwersytet Lubelski Jana Pawła II, Instytut Nauk o Sztuce; adres do korespondencji: Al. Racławickie 14, 20-950 Lublin; e-mail: tomasz.rokosz@kul.pl; ORCID: https://orcid.org/0000-0001-6666-6196.

Dr. Hab. Tomasz Rokosz, John Paul II Catholic University of Lublin, Institute of Art Studies; address for correspondence: Al. Racławickie 14, 20-950 Lublin, Poland; e-mail: tomasz.rokosz@kul.pl; ORCID: https://orcid.org/0000-0001-6666-6196. 
przez Stanisława Nogaja, ucznia Stanisława Wyżykowskiego. Wymienione dwa nazwiska należą do najbardziej znanych na polskim rynku lutniczym w odniesieniu do liry korbowej. Wytwórstwo S. Wyżykowskiego zastało już w znacznej mierze przedstawione w literaturze naukowej i popularnonaukowej (Przerembski, „Innowacje w budowie liry korbowej w Polsce"1; BednarskaKopeć, Lira jako polski instrument ludowy i Z przeszłości liry korbowej w Polsce; Wyżykowski, Lirnik z Haczowa). Niniejszy szkic, prezentujący wytwórstwo najważniejszego jego ucznia, jest w pewnym sensie kontynuacją tego tropu. Asumpt do takiego monograficznego ujęcia daje także okrągła dwudziesta rocznica pracy lutniczej Stanisława Nogaja, przypadająca na początek $2021 \mathrm{r}$.

Podstawą materiałową dla niniejszych badań jest szereg wywiadów terenowych ze Stanisławem Nogajem przeprowadzonych przez autora osobiście w 2021 r. ${ }^{2}$ Wywiady dotyczyły historii powstawania i udoskonalania kolejnych instrumentów, terminologii związanej z budową, procesem wytwarzania i nazewnictwem konkretnych części instrumentu oraz problemów techniki wykonawczej i repertuaru. Zebrano także dokumentację fotograficzną i dostępną literaturę źródłową (naukową i popularnonaukową). ${ }^{3} \mathrm{~W}$ niniejszym artykule, ze względu na jego ograniczoną objętość, wykorzystano jedynie pierwszą część zebranych materiałów.

Stanisław Nogaj urodził się 3 listopada 1978 r. w Brzozowie i przez całe życie zamieszkiwał w Starej Wsi (powiat brzozowski). W przypadku biografii zawodowej tego konstruktora lir korbowych dostrzegamy istotny etap terminowania u konkretnego mistrza, co ułatwiło jego edukację zawodową. Rozwijał on pracownię i warsztat lutniczy od poziomu półprofesjonalnego, który przejął od Stanisława Wyżykowskiego (Lirnik z Haczowa 9-20), w kierunku budowy profesjonalnych instrumentów. Podstawy wytwórstwa instrumentów wypracowane przez Wyżykowskiego przyspieszyły osiągniecie profesjonalnego poziomu budowniczego instrumentów przez jego ucznia. Dotyczy to nie tylko wyposażenia i użycia określonych narzędzi, ale także zastosowania określonych technik, a przede wszystkim wprowadzanych w życie idei (np. rekonstrukcji określonych tradycyjnych modeli lir, ich stopniowe udoskonalanie itd.).

Stanisław Nogaj po raz pierwszy skontaktował się ze Stanisławem Wyżykowskim w 1997 r. w sprawie naprawy gitary. Ponieważ grał amatorsko na tym instrumencie oraz skończył technikum drzewne, a jego wujek był stolarzem,

\footnotetext{
${ }^{1}$ Artykuł obejmuje opis i analizę instrumentów powstałych w pracowni S. Wyżykowskiego do $1992 \mathrm{r}$.

${ }^{2}$ Wykaz przeprowadzonych wywiadów zamieszczono na końcu szkicu.

${ }^{3}$ Dodatkowo wykorzystano niektóre materiały dotyczące liry korbowej zgromadzone przez autora w latach 2013-2021.
} 
zainteresował się warsztatem lutniczym. Ogromne znaczenie, jak sam twierdzi, miał tu charakter Wyżykowskiego - człowieka otwartego na przekazywanie wiedzy, tryskającego energią i humorem (Nogaj, Wywiad 1). Systematyczną naukę u lutnika rozpoczął w 2001 r. ${ }^{4}$ Stanisław Nogaj pracował wtedy w Krakowie w studio nagrań ${ }^{5}$, ale aby poświęcić się wytwórstwu instrumentów złożył wypowiedzenie (Wywiad 1). Dojeżdżał do warsztatu Wyżykowskiego w Haczowie przez prawie trzy lata (Wywiad 1). Relacje między dwoma lutnikami młodszy z nich określił jako przyjaźń mimo dużej różnicy wieku (Wywiad 2). Darzy on mistrza ogromnym szacunkiem, twierdzi jednak, że niejednokrotnie sam go inspirował swoimi pomysłami i rozwiązaniami technicznymi.

Stanisław Nogaj do roku 2021 zbudował przeszło 100 lir korbowych. Jest to liczba imponująca, świadcząca o pracowitości wytwórcy, ale co równie ważne, brzemienna w skutkach w odniesieniu do współczesnej sytuacji muzyki rekonstruowanej. Instrumenty te pozwalają wszak odnowić praktykę gry na lirze korbowej, głównie w Polsce (stosunkowo nieliczne instrumenty trafiały do muzyków i kolekcjonerów zagranicznych).

Generalnie w wytwórstwie instrumentów Stanisława Nogaja obserwujemy dwa procesy: udoskonalania tradycyjnego modelu liry oraz (rzadziej) dążenie do rekonstrukcji (najczęściej na konkretne zamówienie) określonego historycznego egzemplarza liry (Nogaj, Wywiad 3). W jego warsztacie wytwarzane są liry w czterech zasadniczych typach: typ gitarowy; typ „łezka”, typ wiolonczelowy oraz model Santiago. Warto zaznaczyć, że nazwy te pochodzą od kształtu i konstrukcji pudła rezonansowego. Uznawane jest ono zatem za podstawową część instrumentu, od której wywodzony jest cały typ.

Typ gitarowy jest chronologicznie najstarszy (w perspektywie opisywanego wytwórcy), dziedziczony jeszcze po prototypach Stanisława Wyżykowskiego i stopniowo udoskonalany - najpierw przez samego Wyżykowskiego, potem we współpracy ze Stanisławem Nogajem. Łącznie w opisywanym warsztacie do stycznia 2021 r. wykonano 62 egzemplarze lir gitarowych, w tym 7 pierwotnych egzemplarzy (według szablonów Wyżykowskiego), które wytwórca wyraźnie odróżnia. Pozostałych lir gitarowych, powstałych później,

\footnotetext{
${ }^{4}$ Chociaż okazjonalnie widywał się ze Stanisławem Wyżykowskim w latach 1997-2001.

${ }^{5}$ Było to jezuickie studio INIGO (dziś już nieistniejące) przy Wydawnictwie Apostolstwa Modlitwy (WAM)

${ }^{6}$ Wszystkie pochodzące od informatora cytaty z wywiadów zaznaczono kursywą.

${ }^{7}$ Stanisław Nogaj używa często powyższych nazw typów lir pisanych wielką literą (Stanisław Nogaj. Pracownia Liry Korbowej). Na stronie internetowej wytwórcy umieszczono m.in. interesującą i bogatą dokumentację fotograficzną. Nie znajdziemy tam jednak opisywanego w niniejszym artykule rekonstruowanego egzemplarza liry gitarowej.
} 
już udoskonalonych lub wykonanych według własnych projektów, powstało 55. Niezmienny w przypadku lir gitarowych pozostał jednak podstawowy kształt pudła (przy stopniowym minimalnym zwiększaniu jego rozmiarów). Warto dodać, że typ ten często spotykany jest wśród tradycyjnych, historycznych lir występujących we wschodniej Polsce.

Przejdźmy więc do szczegółowego opisu i analizy egzemplarza liry gitarowej zbudowanego w 2004 r., który określimy jako LG1 (określenie autora artykułu). Był on kopią liry dziadowskiej, pozostającej w zbiorach Muzeum Etnograficznego im. Seweryna Udzieli w Krakowie (fotografia 1). Oznaczymy go jako LD MEK. Egzemplarz pochodzi z XIX w. z Wołynia. Warto zaznaczyć, że jest on bardzo podobny do instrumentu Iwana Własiuka, uznawanego za ostatniego tradycyjnego lirnika, reprezentującego tradycję wołyńską (por. Lirnyts 'ki pisni z Polissya 96-98). Podobna jest zarówno forma pudła rezonansowego, jak i inne rozwiązania: podstawki, czoło skrzynki tangentowej (w obu przypadkach zakończona jest ona przy kole charakterystycznym łukiem, pełniącym głównie funkcję zdobienia. Można więc powiedzieć, że mamy tu do czynienia $z$ wołyńskim typem liry, będącym najbliżej tradycji polskiej, o ile tradycja taka (wytwarzania instrumentów) w ogóle w przeszłości istniała. Przy obecnym stanie wiedzy nie możemy jeszcze wyczerpująco rozstrzygnąć kwestii jak rozumieć określenie „polska lira korbowa” ${ }^{8}$. Warto jednak postawić pytanie: Jak się ma do polskiej tradycji opisywany rekonstruowany egzemplarz? Niewątpliwe jest występowanie lir korbowych we wschodniej Polsce, niezależnie od tego skąd pochodziły (kto je wytwarzał) i czy grali na nich polscy (zapewne bardzo rzadko, ale znamy takie przypadki ${ }^{9}$ ), czy też ukraińscy lirnicy ${ }^{10}$. Należy również mieć świadomość, że w okresie zaborów nie istniało formalnie państwo polskie. Możemy więc przyjąć, że tradycja lirnicza funkcjonowała w skomplikowanym historycznie, wielokulturowym i wieloetnicznym kontekście wschodniej Polski. O tak zarysowanym stanie kultury muzycznej XIX i XX wieku na opisywanych terenach świadczą także historyczne instrumenty w zbiorach muzealnych (por. Bednarska-Kopeć, Lira jako polski instrument ludowy; Przerembski, „Innowacje w budowie liry” 91-104). Tylko uwzględniając powyższe zastrzeżenia, opisywany typ gitarowy można nazwać „polskim”. Opisywany egzemplarz LD MEK jest uznawany za lirę ukraińską i tak został zinwentaryzowany w muzealnych zbiorach.

\footnotetext{
${ }^{8}$ Określenie to było używane wielokrotnie przez Wyżykowskiego (por. Wyżykowski).

${ }^{9}$ Przykładowo o takich lirnikach i ich repertuarze (z okolic Sandomierza i Tarnobrzega) wspomina Ferdynand Kuraś (45; por. też Iwaszkiewicz 164, 185-86).

${ }^{10}$ Problem ten sygnalizowałem już wcześniej (por. Grochowski, „Polscy dziadowie” 165).
} 


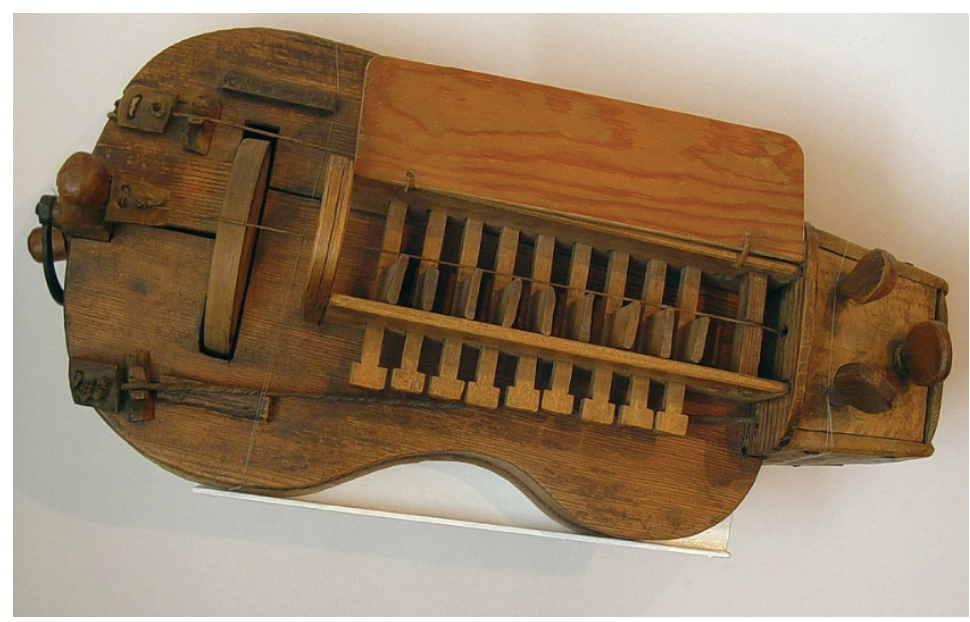

Fotografia 1. Lira dziadowska (LD) w zbiorach Muzeum Etnograficznego im. Seweryna Udzieli w Krakowie

Egzemplarz LD MEK charakteryzował się dużą prostotą i dość amatorskim wykonaniem (co przekładało się zapewne na dość niskie walory brzmieniowe tego instrumentu). $Z$ tego też powodu możemy go uznać za instrument sensu stricto ludowy. Zgodnie $\mathrm{z}$ intencjami wytwórcy egzemplarz liry gitarowej LG1 miał być kopią LD MEK, jednak z zastosowaniem pewnych innowacji, które poprawiałyby jego brzmienie (zostaną one uwzględnione w opisie porównawczym instrumentów). Nie miała to być więc rekonstrukcja wierna $\mathrm{w}$ stu procentach. Zgodnie z założeniem podstawowe elementy konstrukcyjne, kształt pudła rezonansowego oraz wymiary instrumentu są identyczne z modelem wzorcowym. Odpowiednio więc LG1 to lira o następujących wymiarach: długość $64 \mathrm{~cm}$ (po koniec korby), szerokość $27 \mathrm{~cm}$, wysokość $18 \mathrm{~cm}$ (najwyższą część liry stanowi luczek, który jest zakończeniem skrzynki tangentowej) (fotografia 2). 


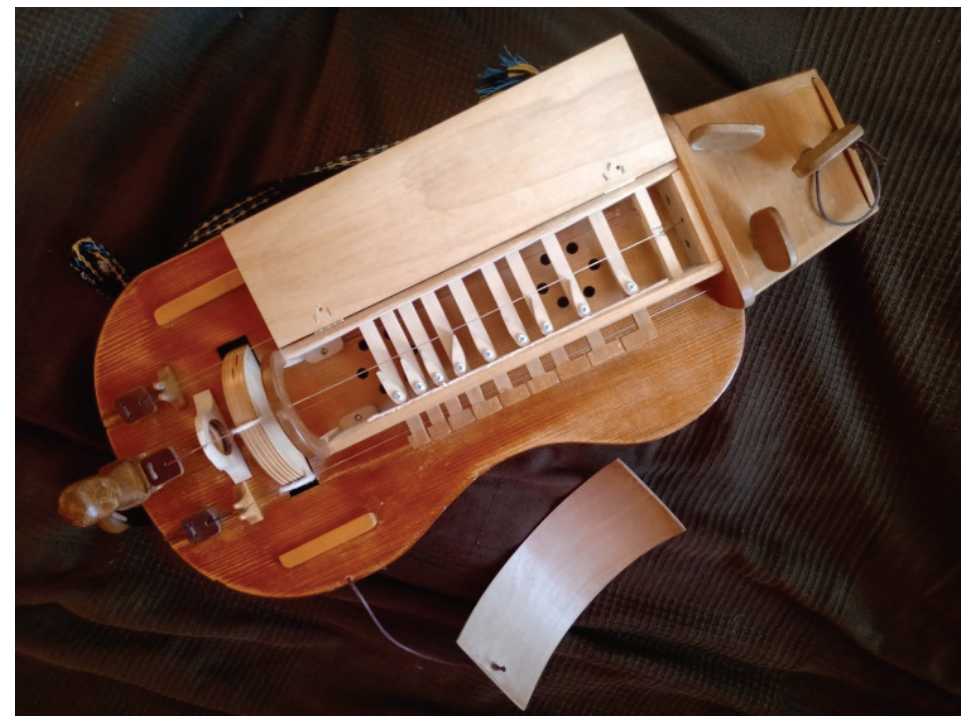

Fotografia 2. Lira gitarowa (LG1), wykonana na podstawie liry muzealnej LD

Jest to lira jednorzędowa, diatoniczna, z dziewięcioma klawiszami. Pewnym problemem przy rekonstrukcji była interpretacja braku dziesiątego najniższego klawisza - w egzemplarzu muzealnym widzimy na fotografii jedynie otwór po nim. Szczegółowe pomiary Stanisława Nogaja wykazały, że klawisz ten prawdopodobnie był błędnie umiejscowiony, tj. za blisko prożka (Nogaj, Wywiad 8). Być może więc nie został w ogóle wykonany - w tym układzie niemożliwe lub bardzo trudne byłoby jego prawidłowe wystrojenie. W związku $\mathrm{z}$ taką interpretacją ${ }^{11}, \mathrm{w}$ LG1 wytwórca wykonał 9 klawiszy ${ }^{12}$. W LD MEK klawisze były rozmieszczone równomiernie, natomiast w LG1 S. Nogaj rozmieścił je nieco inaczej - precyzyjniej - w pewien sposób „ulepszając” pierwotny system (ewentualnie likwidując pierwotny błąd w ich rozmieszczeniu) (Nogaj, Wywiad 9). Lira LG1 strojona była w tonacji g (struna melodyczna $\mathrm{g}^{1}$ ) i posiadała kolejno tangenty: a, h, c, d, e, f, g, a, h. W efekcie strój i skala rekonstruowanego instrumentu przedstawiały się w sposób następujący: g: $d^{1}: g^{1} ; g^{1}-h^{2}$.

${ }^{11}$ Istotna jest tu konstatacja Zbigniewa Przerembskiego („Innowacje w budowie liry” 93): „Skalę i strój tradycyjnych polskich lir, instrumentów historycznych trudno sprecyzować ze względu na brak przekazów źródłowych. Zachowane w muzeach egzemplarze tego instrumentu (głównie z XIX w.) znajdują się w różnym stanie, często niekompletnym [...], w związku z czym o skali instrumentu można wnioskować jedynie ogólnie, na podstawie liczby i ułożenia klawiszy”.

${ }^{12}$ Warto dodać, że lira wspomnianego na początku artykułu Iwana Własiuka z Wołynia posiadała jedenaście klawiszy. Instrument ten (podobnie lira Nogaja) dedykowany był tonacji g. Jak wynika z zamieszczonych transkrypcji, strojony był pół tonu niżej, dwa burdony - fis: cis ${ }^{1}$ (por. Lirnyts 'ki pisni z Polissya 47, 98). 
Warto dodać, że we wszystkich późniejszych modelach gitarowych tego typu (z klawiaturą diatoniczną) wytwórca lokalizował tangenty tak jak w opisywanym egzemplarzu, to znaczy pierwszy klawisz/tangent pomiędzy dźwiękami as i a. W efekcie można go było stroić ręcznie tzw. chorągiewką zarówno na dźwięk as, jak i na dźwięk a. Taka sama zasada obejmowała drugi klawisz, natomiast trzeci klawisz i następne (dla całej pierwszej oktawy) lokalizowane były już na środku, z możliwością przestrojenia o pół tonu zarówno w górę, jak i w dół - przykładowo klawisz c - na $\mathrm{h}^{1}$ i na cis ${ }^{1}$. Odnośnie do poruszonego problemu istotny jest też fakt, że im więcej jest klawiszy (dotyczy to zwłaszcza wyższych dźwięków drugiej oktawy), tym trudniej jest wystroić czysty, wysoki dźwięk. Im bliżej koła, tym odległości dla rozmieszczenia klawiszy zmniejszają się, a dodatkowo struny wchodzą w charakterystyczny pisk lub nie grają w ogóle. W praktyce każdy detal składa się na czystość uzyskanego dźwięku. Duże znaczenie ma zwłaszcza wykonanie otworu na suwak, wypolerowanie suwaka i otworu na niego, umieszczenie chorągiewki tak, aby dotykała do struny tzw. miękką częścią, a nie na sztorc. O jakości ostatecznie emitowanego dźwięku decydują też profesjonalne struny. Przedstawione kwestie szczegółowe wyjaśniają, dlaczego tradycyjne egzemplarze lir dziadowskich, wytwarzane przecież w sposób amatorski, dysponowały najczęściej niewielką skalą klawiatury, nieznacznie przekraczającą jedną oktawę, i liczbą klawiszy od 9 do $12^{13}$.

Odnośnie do techniki gry warto dodać, że instrument tego typu musi być trzymany na kolanach w pozycji około 30 stopni pochylenia. Liry dziadowskie miały duże luzy w otworach na klawisze, które zapewniały samoczynny powrót klawiszy w tej pozycji (klawisze nie zacinały się).

W LD MEK założone były trzy oryginalne struny jelitowe. W LG1 zastosowano natomiast trzy struny metalowe skrzypcowe $\left(g, d^{1}, a^{1}\right)$ w następującym stroju $-\mathrm{g}: \mathrm{d}^{1}: \mathrm{g}^{1}$. Dwie pierwsze to burdony, natomiast jako struna melodyczna wykorzystana została struna skrzypcowa $a^{1}$ strojona o cały ton niżej na $\mathrm{g}^{1}$. Umożliwiała to krótka menzura instrumentu, zbliżona do skrzypiec ${ }^{14}$. Motywacją dla takiego wyboru strun była zarówno łatwość zdobycia strun skrzypcowych w tamtym czasie (struny jelitowe były wówczas w Polsce trudno dostępne), jak i tradycja wytwórcza warsztatu Wyżykowskiego, z której Stanisław Nogaj wtedy bezpośrednio korzystał.

Menzura struny melodycznej $\mathrm{g}^{1}$ (kluczowa w stosunku do budowy klawiatury) wynosiła w opisywanym instrumencie $325 \mathrm{~mm}$. Menzura burdonu

\footnotetext{
${ }^{13}$ Taką liczbę klawiszy miały liry ukraińskie (Przerembski, „Innowacje w budowie liry” 93).

${ }^{14} \mathrm{~W}$ późniejszych modelach, w których zwiększono menzurę, Nogaj wykorzystywał także struny od altówki.
} 
$\mathrm{d}^{1}-340 \mathrm{~mm}$ (zmiana w stosunku do struny melodycznej, ponieważ zastosowano grubszą strunę, która musiała być oddalona od koła, a w związku z tym podstawki zostały ustawione nieco dalej). Menzura drugiego burdonu g wynosiła także $340 \mathrm{~mm}$.

Pudło rezonansowe. $W$ instrumencie zastosowano świerkową płytę wierzchnią, wszystkie inne części pudła wykonano z drewna jaworowego (boki i płyta spodnia $)^{15}$, natomiast kołki do strojenia i klawisze - $\mathrm{z}$ drewna grabowego. Pudło rezonansowe składało się z boczków, płyty spodniej (z dwu elementów), płyty wierzchniej (z dwu elementów), dwóch klocków, czterech wzmocnień, sześciu belek. Użyto też, jak zawsze w przypadku lir, trzy dusze. Dwa pieńki (Wyżykowski nazywał je klockami) od środka łączyły dwie części boczków. W pudle rezonansowym LD MEK nie wycięto otworów rezonansowych - funkcję tę spełniał otwór na koło. W LG1 inaczej niż w modelu wzorcowym wykonano rozetkę wierconą, ponieważ brak otworów rezonansowych powodował, że instrument był bardzo cichy (Nogaj, Wywiad 9). W związku z tym już po jego wykonaniu wytwórca rozwiercił $\mathrm{w}$ wierzchniej płycie wewnątrz skrzynki tangentowej otwory $\mathrm{w}$ formie rozety (tzw. rozeta heksapentalna $-\mathrm{z}$ jednym otworem w środku). Spełniała ona funkcję otworu rezonansowego i w mniejszym stopniu (ponieważ w związku z lokalizacją była słabo widoczna) funkcję estetyczną.

Skrzynka tangentowa. Tangenty, nazywane też często chorągiewkami (nieprofesjonalne, synonimiczne określenie tangentu) wykonano $\mathrm{z}$ jaworu. Klapka nad skrzynką tangentową była otwierana, przy czym zawiasy do klapy zaczepiono na rzemykach skórzanych z pętelką z rzemienia wiązaną na supeł (w modelu LD MEK była to struna jelitowa). Funkcję prożka struny melodycznej pełniła (tak jak w LD MEK) listewka, na której opiera się struna. Dalej, poza prożkiem, struna przechodziła przez otwór w ścianie komory kołkowej i była okręcana na kołku.

Koło wykonano ze sklejki, bez okleiny (inaczej niż w egzemplarzu wzorcowym), w którym było ono zrobione z jednego kawałka drewna, prawdopodobnie miękkiego - być może z sosny, jodły lub świerku. W LG1 wykonano stalowa ośkę (pręt, który wchodził w koło), a na końcu ośki zamocowano na gwincie korbę. Ośka opierała się na dwóch tulejkach - pierwsza mocowana w boczku i pieńku, druga montowana w poprzecznej belce. Rolę łożysk pełniły tulejki hebanowe. W LD MEK z pewnością nie było łożysk, natomiast nie wiadomo, jak była wykonana tam ośka i tulejki. Najprawdopodobniej (kategoryczne stwierdzenie wymagałoby dokładnego zbadania instrumentu od środka)

${ }^{15}$ Wytwórca stwierdził, że w egzemplarzu wzorcowym płyta w pudle rezonansowym była świerkowa, natomiast rodzaj drewna w innych częściach instrumentu trudno było określić (Nogaj, Wywiad 3). 
instrument ten nie posiadał ośki i tulejek, a otwór na koło wiercony był w samej belce. W związku z tym koło nie było stabilne - jak stwierdził lutnik: pracowało „jak chciało” - bardzo luźno (Nogaj, Wywiad 4). Warto dodać, że w muzealnym oryginale nie użyto też hebanu.

LD MEK pierwotnie wyposażona była też zapewne w osłonę kola (nie wiemy, jak wyglądała), o czym świadczą dwie listewki służące do trzymania osłony, zlokalizowane na górnej płycie. W LG1 osłonę koła wykonano z jednego kawałka drewna, natomiast listewki do osłony są wierną kopią z LD MEK.

W LG1 zastosowano unowocześnioną w stosunku do LD MEK korbę, zbudowaną z małej ośki, na której zamocowana została gałka $\mathrm{z}$ drewna jaworowego, z łącznikiem gałki z mosiądzu w kształcie uproszczonej litery „c”. Zastosowano też inne zamocowanie korby: jest ona odkręcana od ośki (w LD MEK jest zespolona $\mathrm{z}$ ośką na stałe). Do łącznika korby przymocowana jest sześciokątna nakrętka, za pomocą której nakręca się korbkę na ośkę. Jest to udoskonalenie bardzo pomocne zwłaszcza w transporcie instrumentu - chroni przed złamaniem lub odkształceniem korby. Korba w LG1 dodatkowo ozdobiona jest prostym wzorem wykutym (wybijanym) w metalu.

Skrzynka kołkowa (nazywana też komorą kołkową lub główką, gdy montowane są w niej klucze) i w oryginale, i w reprodukcji była „zamknięta”: boczki skrzynki kołkowej oraz deseczka górna i spodnia tworzyły przestrzeń zamykaną specjalną deseczką „licową”, wprowadzaną od góry na wyciętej w bocznych ściankach skrzynki prowadnicy (fotografia 3 ).

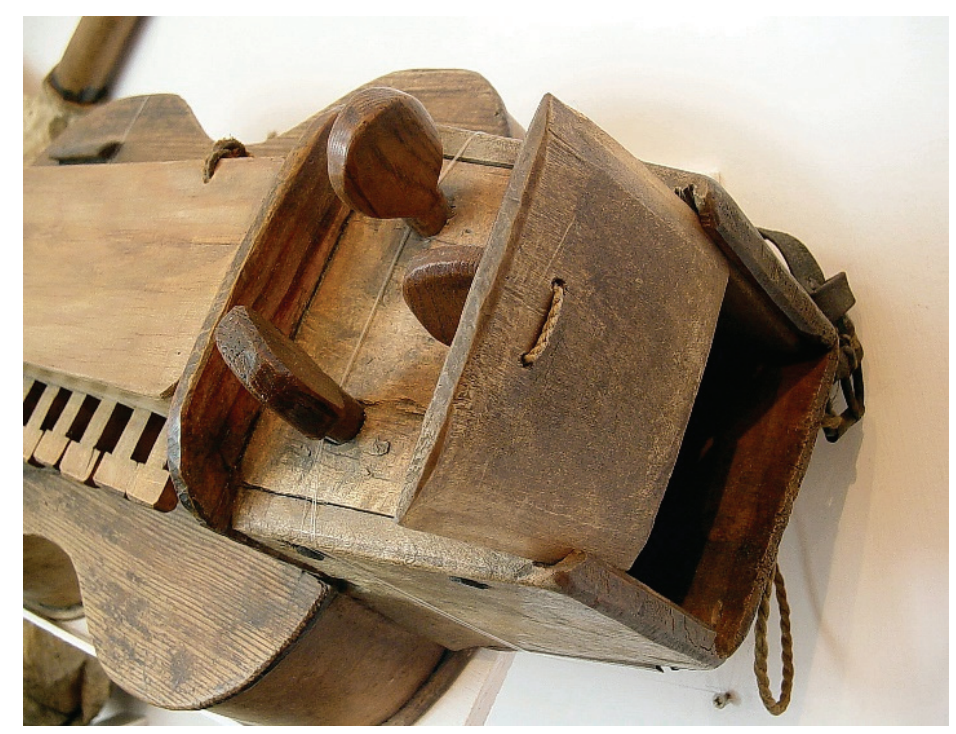

Fotografia 3. Zamknięcie skrzynki kołkowej 
W ten sposób powstawała izolowana komora kołkowa, która zabezpieczała tę część instrumentu przed wilgocią, ale mogła też służyć jako schowek. Należy dodać, że deseczka spodnia skrzynki kołkowej jest w tym przypadku przedłużeniem płyty spodniej, ale w obu modelach wykonano jeszcze deseczkę środkową z nawierconymi otworami, w które wprowadzano od góry kołki. Pełniła ona funkcję stabilizatora kołka. W komorze kołkowej zastosowane zostały w związku z tym drewniane „schodki”, które należy traktować jako wzmocnienie konstrukcyjne. W LD MEK widzimy kołki ręcznie strugane, natomiast Stanisław Nogaj zastosował kołki grabowe, toczone na maszynie, a później obrabiane pilnikiem - w ten sposób nadał on kołkowi precyzji (co jest bardzo istotne przy późniejszym strojeniu instrumentu). Kołki wykonane przez wytwórcę są też równomierne i nieco większe niż w LD MEK.

W omawianym modelu, zgodnie z pierwowzorem, zamontowano strunociąg (do struny melodycznej) w formie tzw. główki dziada. Spełniała ona więc jednocześnie funkcję strunociągu oraz funkcję zdobienia (por. fotografia 4). Zaczepy dwóch strun burdonowych miały natomiast formę tzw. klocka (spotykanego w najprostszych modelach lir). Funkcję podstawków przy główce instrumentu pełniła skrzynka kołkowa. Od strony koła, zarówno w LD MEK, jak i LG1, podstawki nie są przymocowane do pudła rezonansowego - można je przesuwać (por. fotografia 4). Klocek był łączony rzemieniem (w LG1 struną lub sznurem) ze spodnią płytą, w której wywiercono dwa otwory z przewleczonym sznurkiem. Taki sposób mocowania dwóch strun miał prawdopodobnie względy praktyczne - struny jelitowe były krótkie, a zaczepione o płytę wierzchnią niszczyłyby ją bardziej niż spodnią (choć i takie rozwiązania były praktykowane, zwłaszcza w lirach węgierskich). Cała opisana konstrukcja pełni funkcję strunociągu strun burdonowych. Element zaczepienia struny (część strunociągu) w LG1 ma nieco inny kształt niż w LD MEK, gdzie pierwotnie był on trapezowy, natomiast w wykonaniu Nogaja usystematyzowany - kwadratowy. W LD MEK widzimy najprawdopodobniej struny z jelit baranich preferowane ze względu na dużą wytrzymałość. 


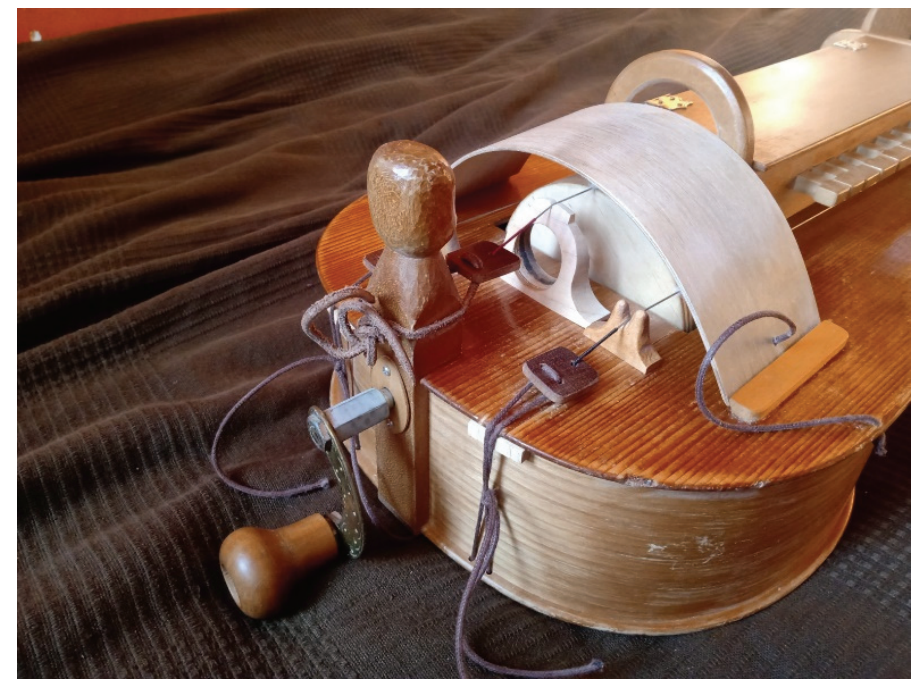

Fotografia 4. Zaczepy strun w lirze LG1

Szczegółowych różnic konstrukcyjnych pomiędzy LD MEK a LG1 widzimy jednak więcej. W omawianej rekonstrukcji tangenty nie są „typu chorągiewkowego" (tangent przytwierdzany na kołeczek wciskany w okrągły otwór w suwaku), ale mocowane na wkręt.

Dodać należy, że opisywana rekonstrukcja okazała się w praktyce niewystarczająca dla konkretnych muzyków grających na omawianym modelu liry. Opisany instrument był „poprawiany” przez swoich późniejszych użytkowników. Modyfikacji dokonał głównie Krzysztof Busk (kolejny użytkownik liry), który zmienił podstawek melodyczny na swój autorski - stylizowany na węgierski i założył w klapce skrzynki tangentowej zawiasy zamiast rzemyka (zmiany te są widoczne na zdjęciach, nie zachowały się bowiem fotografie oddające pierwotny wygląd instrumentu). Widzimy też, że (po zmianach Buska) podstawki są przesunięte $\mathrm{w}$ stronę koła, prawdopodobnie menzurę burdonów wyrównano do struny melodycznej. Do dziś w instrumencie używane są także struny metalowe z nawiniętą watą. W LD MEK najprawdopodobniej nie używano waty do otaczania strun w miejscu ich zetknięcia z kołem (nie ma jej śladów). W LG1 była ona stosowana w celu zmiękczenia brzmienia - niweluje efekt uderzania wibrującej struny o drewniane koło (charakterystyczne „syczenie”).

Różnica w kolorze obu instrumentów wynika z ich wieku (kolor ciemnieje wraz z upływem lat). Być może egzemplarz LD MEK był nasączony jakimś specyfikiem - może zaimpregnowany politurą - ale ten środek został zniszczony (na zdjęciu widać „strupki” na płycie wierzchniej). Klapa skrzynki tangentowej 
w LD MEK mogła być dorobiona - ma bowiem inny kolor niż cały instrument. Zamiast paska (zwykle stosowanego we współczesnych lirach) w LG1 zastosowano pierwotnie sznurek parciany, zaczepiony do instrumentu za pomocą guzika skrzypcowego.

Do klejenia elementów wytwórca użył (tak jest też w przypadku jego kolejnych modeli lir) klejów skórnych, których używano w tradycyjnym lutnictwie ${ }^{16}$. Stosowane były na gorąco - klej podgrzany do $70^{\circ} \mathrm{C}$ wymaga $\mathrm{w}$ tym przypadku tzw. klejenia w tempie, gdyż stygnący klej żeluje (Nogaj, Wywiad 4).

Podsumowując, egzemplarz LG1 miał być rekonstrukcją muzealnego wzorca. Bardzo istotne było $\mathrm{w}$ tym przypadku zachowanie zewnętrznego wyglądu instrumentu, co uniemożliwiało zastosowanie wielu innowacji (np. elementów współczesnych lub pochodzących od innych instrumentów). Wprowadzone zmiany dotyczą natomiast (w niewielkim stopniu) opisanych elementów konstrukcyjnych. Zastosowane w LG1 nieliczne innowacje miały charakter „techniczny" - służyły uzyskaniu dźwięku akceptowalnego przez współczesnego wykonawcę i odbiorcę. Instrument zbudowany był na zamówienie, dla potrzeb określonych sztuk teatralnych ${ }^{17}$. W związku z tym omawiany model miał nie tylko grać, ale także „wyglądać”, tzn. dobrze prezentować się na scenie. Miał służyć głównie do akompaniowania przy śpiewaniu tradycyjnych pieśni dziadowskich i kopiować oryginalne brzmienie pierwowzoru, określane przez lutnika jako nieco siermiężne i przaśne (Nogaj, Wywiad 1). Należy wyraźnie zaznaczyć, że brzmienie to nie jest znane (możemy się go jedynie domyślać), gdyż opisywany instrument LD MEK był jedynie muzealnym eksponatem i nie było możliwości grania na nim (wymagałoby to poważnych ingerencji lutniczych). W efekcie pierwotne brzmienie instrumentu można było zrekonstruować budując jego wierną kopię. Warto jednak pamiętać, że na ostateczne brzmienie liry korbowej ogromny wpływ mają niuanse przedstawione w artykule (typ założonych strun, użycie waty, materiał, z którego zrobione jest koło, stopień precyzji wykonanych elementów). ${ }^{18}$ Te drobne szczegóły przesądzają o dźwięku, który ostatecznie wydobywamy z instrumentu. Zbudowana kopia oryginalnego instrumentu dziadowskiego pozwala $\mathrm{w}$ każdym razie na dalsze szczegółowe eksperymenty brzmieniowe (łącznie $\mathrm{z}$ wymianą określonych elementów).

\footnotetext{
${ }^{16}$ Oprócz klejów skórnych (powstałych na bazie gotowanych skór zwierząt), używano także klejów kostnych, ale tych Stanisław Nogaj nie używa (Nogaj, Wywiad 3).

${ }^{17}$ Wykonany był na zamówienie Dariusza Kunowskiego, założyciela warszawskiego teatru Scena Lubelska 30/32.

${ }^{18}$ Pomijam tu kwestie samej techniki grania, także przecież istotnej w perspektywie brzmienia liry korbowej.
} 
Pomimo zastosowanych innowacji, lira LG1 według Stanisława Nogaja brzmiała dość przaśnie, nie miała czystego dźwięku, ale brzmienie byto jednak oczyszczone z szumów i drgań klawiszy (którymi prawdopodobnie cechował się oryginał) (Wywiad 4). Sąd ten potwierdzony jest też przez późniejszych użytkowników opisywanego egzemplarza liry. Krzysztof Busk, który grał na niej najdłużej, twierdził, że lira świetnie brzmi, jest głośna i dobrze się na niej gra (Wywiad 8). Instrument ten był używany m.in. na warsztatach lirniczych w Koźlikach ${ }^{19}$. Stanisław Nogaj twierdzi, że zrekonstruowany instrument nie miat w stu procentach charakteru dziadowskiego (Wywiad 4). Ogólny charakter pierwowzoru został jednak zachowany. $Z$ zasygnalizowanych powyżej, wprowadzonych w omawianym egzemplarzu innowacji, najbardziej istotne było zastosowanie koła ze sklejki, które spowodowało wyrównanie brzmienia. $\mathrm{W}$ oryginalnym instrumencie, w którym było ono zrobione $\mathrm{z}$ jednego kawałka drewna, koło pracowało w zależności od wilgoci otoczenia i było prawdopodobnie przyczyną rzężącego dźwięku strun (tzw. pływanie dźwięku - raz niżej, raz wyżej, w trakcie jednego obrotu koła). Zgodnie z intencją wytwórcy złagodzono więc oryginalną szorstkość brzmienia (prawdopodobna cecha modelu LD MEK), którą uznano współcześnie za trudną do przyjęcia. Jest to m.in. konsekwencją tego, że współczesne standardy wykonawcze i przyzwyczajenia słuchaczy zmieniły się w stosunku do kultury tradycyjnej XIX i pierwszej połowy XX wieku. Przedstawiona teza prowadzi nas do wniosku, że ścisła rekonstrukcja wszystkich elementów (możliwa przecież do wykonania), byłaby afunkcjonalna (z perspektywy wytwórcy, wykonawcy i odbiorcy). Nierówne koło cechowało tradycyjne instrumenty z XIX wieku, co w tamtym czasie było do przyjęcia. Według wytwórcy dziś ogólne cechy brzmieniowe instrumentu trzeba trochę wypolerować (czystość brzmienia, dostrojenie strun i tangentów) (Wywiad 2). Należy wyeliminować największe niedoskonałości pierwowzoru przy zachowaniu podstawowej konstrukcji instrumentu (liczba klawiszy, wielkość oraz budowa pudła rezonansowego i innych ważnych elementów). Zgodnie z intencją lutnika ,wygładzone” zostały jedynie drobne szczegóty (Wywiad 3).

Powszechnie uważa się, że dany instrument historyczny jest przyporządkowany do określonego czasu, epoki, a często i warstwy społecznej. Przedsta-

\footnotetext{
${ }^{19}$ Warsztaty w Koźlikach, w ramach projektu „Wyśpiewać podlaską tradycję - rok obrzędowy w pieśniach i rękodziele”, były cykliczną imprezą realizowaną przez Stowarzyszenie Dziedzictwo Podlasia we współpracy z Muzeum Podlaskim, dofinansowaną przez Urząd Marszałkowski Województwa Podlaskiego. Organizowane były przez Julitę Charytoniuk. Część projektu adresowana była do współczesnych lirników. Przykładowo w marcu 2011, 2013 i 2015 r. warsztaty lirnicze prowadził Serhij Petryczenko (Wywiad 8; por. też „Warsztaty pieśni lirniczych”).
} 
wiony $\mathrm{w}$ artykule przypadek pokazuje także, że rekonstrukcja funkcjonalna instrumentu historycznego - gdy ma on służyć przede wszystkim do grania może uwzględniać rozwój i przemiany kultury muzycznej.

Problem współczesnej funkcji instrumentu rekonstruowanego prowadzi do postawienia podstawowych pytań: Do czego konkretnie instrument ma służyć? Dla kogo jest wykonywany? W jakim zakresie ma kopiować parametry muzyczne pierwotnego modelu? Z zebranych materiałów źródłowych wynika, że mechaniczne kopiowanie niedoskonałości oryginału (gdy dysponujemy lepszymi rozwiązaniami i bardziej rozwiniętym warsztatem) jest często trudne do przyjęcia przez współczesnego wytwórcę. Nie bez znaczenia jest tu posługiwanie się kompetencją kulturową, która jest wynikiem szczegółowej wiedzy praktycznej i historycznej.

\section{BIBLIOGRAFIA}

\section{MATERIALY TERENOWE}

Archiwum Autora.

Wyżykowski, Stanisław. „Pogadanka na temat liry korbowej wygłoszona w Narolu w 2013 r.” Zarejestrował Tomasz Rokosz, 2013.

Wywiady Autora ze Stanisławem Nogajem zarejestrowane w Starej Wsi (powiat brzozowski):

Wywiad nr 1, 27.01.2021.

Wywiad nr 2, 29.01.2021.

Wywiad nr 3, 2.02.2021.

Wywiad nr 4, 4.02.2021.

Wywiad nr 8, 22.02.2021.

Wywiad nr 9, 24.02.2021.

\section{LITERATURA}

Bednarska-Kopeć, Anna. Lira jako polski instrument ludowy. Jej dzieje, budowa, repertuar. Studium historyczno-folklorystyczne. Uniwersytet Wrocławski, 1979. Niepublikowana rozprawa doktorska.

Bednarska-Kopeć, Anna. „Z przeszłości liry korbowej w Polsce”. Polskie instrumenty ludowe. Studia folklorystyczne, red. Adolf Dygacz, Alojzy Kopoczek, Uniwersytet Śląski, 1981, ss. 29-57.

Dahlig, Piotr. „Lirnik jako postać mediacyjna między ziemią a niebem”. Traditional Musical Cultures in Central-eastern Europe. Ecclesiastical and Folk Transmission, red. Piotr Dahlig, Uniwersytet Warszawski (Instytut Muzykologii), Instytut Sztuki PAN, 2009, ss. 415-428.

Grochowski, Piotr. Dziady. Rzecz o wędrownych żebrakach i ich pieśniach. Wydawnictwo Naukowe UMK, 2009. 
Grochowski, Piotr. „Polscy dziadowie i ukraińscy lirnicy. Fakty, stereotypy i perspektywy badawcze”. Piotr Grochowski, Jarmark tradycji. Studia i szkice folklorystyczne, Wydawnictwo Naukowe UMK, 2016, ss. 165-179.

Iwaszkiewicz, Jarosław. Podróże do Polski. Alfa, 1987.

Kononenko, Natalie. Ukrainian Minstrels: And the Blind Shall Sing. M. E. Sharpe, 1998.

Kuraś, Ferdynand. Przez ciernie żywota. A. Gmachowski, 1925.

Lirnytski pisni z Polissya. Materialy do vyvchennya lirnyts 'koyi tradytsiyi. Zapysy vporyadkuvannya i prymitky Oleksiya Oshurkevycha, notni pryklady Yuriya Rybaka, 2002 [Лірнииькі пісні з Полісся. Матеріали до вивчення лірницької традииії. Записи впорядкування і примітки Олексія Ошуркевича, нотні приклади Юрія Рибака, 2002], www.conservatory.lviv.ua/wpcontent/uploads/2016/07/pblk-6_lirnycki-pisni.pdf. Dostęp 22.01.2021.

Michajłowa, Katia. „Dziad wędrowny jako postać mediacyjna w kulturze ludowej Słowian”. Fascynacje folklorystyczne. Księga poświęcona pamięci Heleny Kapetuś, red. Anna Engelking, Agade, 2002, ss. 101-108.

Michajłowa, Katia. Dziad wędrowny w kulturze ludowej Stowian. Tłum. Hanna Karpińska, Oficyna Naukowa, 2010.

Przerembski, Zbigniew Jerzy. „Innowacje w budowie liry korbowej w Polsce”. Muzyka, nr 3-4, 1993, ss. 91-104.

Przerembski, Zbigniew Jerzy. „Z dziejów praktyki lirniczej na ziemiach Rzeczypospolitej”. Muzyka, nr 3, 1996, ss. 95-107.

Stanisław Nogaj. Pracownia Liry Korbowej, www.lirakorbowa.com. Dostęp 28.01.2021.

„Warsztaty pieśni lirniczych oraz gry na lirze korbowej”. MuzykaTradycyjna.pl, www.muzykatradycyjna.pl/pl/kalendarz/warsztaty-piesni-lirniczych-oraz-gry-na-lirze-korbowej. Dostęp 29.01.2021.

Wyżykowski, Stanisław. Lirnik z Haczowa. Nonparel, 2000.

\section{LIRA KORBOWA - INSTRUMENT ZAPOMNIANY? \\ WSPÓŁCZESNA PRAKTYKA REKONSTRUKCJI I BUDOWANIA INSTRUMENTÓW W PRACOWNI LUTNICZEJ STANISŁAWA NOGAJA}

Streszczenie

W artykule poruszona została problematyka współczesnego wytwórstwa liry korbowej. W polu zainteresowań autora znalazły się instrumenty budowane przez Stanisława Nogaja ze Starej Wsi ucznia Stanisława Wyżykowskiego z Haczowa. Do szczegółowego opisu i analizy wybrano egzemplarz zbudowany w 2004 r. - model liry gitarowej. Był on kopią liry dziadowskiej, pozostającej w zbiorach Muzeum Etnograficznego im. Seweryna Udzieli w Krakowie. Podstawą materiałową dla niniejszych badań były głównie źródła wywołane - wywiady terenowe przeprowadzone przez autora osobiście w pracowni S. Nogaja w 2021 r. oraz zebrana dokumentacja fotograficzna. Szczegółowo opisano budowę, zastosowane innowacje i ogólną ideę powstania analizowanego instrumentu.

Słowa kluczowe: lira korbowa; lira dziadowska; rekonstrukcja instrumentu muzycznego; innowacje; Stanisław Nogaj; Stanisław Wyżykowski. 


\section{THE HURDY GURDY - A FORGOTTEN INSTRUMENT? THE CONTEMPORARY PRACTICE OF RECONSTRUCTING AND MANUFACTURING INSTRUMENTS IN THE LUTHIER WORKSHOP OF STANISŁAW NOGAJ}

\section{S u m m a ry}

This article explores the issue of the contemporary manufacture of the hurdy gurdy. The author focuses on instruments built by Stanisław Nogaj from Stara Wieś, a pupil of Stanisław Wyżykowski from Haczów. For a detailed description and analysis, a specimen built in 2004 was chosen - a model of a lyre guitar which is itself a copy of a traditional (beggars') hurdy-gurdy in the collection of the Seweryn Udziela Ethnographic Museum in Kraków. The material basis for this research was mainly field interviews conducted by the author in Stanisław Nogaj's workshop in 2021, and photographic documentation. The construction, the innovations applied, and the general idea of creating the instrument are described in detail.

Keywords: hurdy-gurdy; beggars' hurdy-gurdy; reconstruction of musical instrument; innovations; Stanisław Nogaj; Stanisław Wyżykowski. 